\title{
PROSES LITERASI HUKUM ADAT KAMPUNG TARUNG NUSA TENGGARA TIMUR : UPAYA PENGAKUAN EKSISTENSI
}

\author{
Miranda Risang Ayu Palar, Lailani Sungkar \\ Fakultas Hukum Universitas Padjadjaran \\ Jalan Dipati Ukur No. 35 Bandung, Jawa Barat 40265 \\ lailani@unpad.ac.id
}

\begin{abstract}
Legal means to obtain the recognition of indigenous communities in Indonesia are still scattered in a number of different regulations. Law on Village 2014 also obligates the government to arrange the system to conduct legal acknowledgements for Adat Villages. Tarung Village is a traditional village which situated in West Sumba Regency. The Members are still living in their own customary laws and embracing their local spiritual belief system as a living culture. Until recently, their village haven't yet enjoyed the formal ackonwledgement they deserve as a united indigenous community nor as Adat Village. A number of mechanisms to obtain the acknowledgment require particular processes of identification and validation. This research is an initial effort to undertake the processes. In addition, it also aims to conduct a defensive legal protection by documenting the customary laws with interview method. The result displays the legal means to gain the existential acknowledgement which had been undertaken by the custodians of The Village and the Local Government.
\end{abstract}

Keywords: tarung village; the united of indigenous community; village, defensive protection

\begin{abstract}
Abstrak
Mekanisme dan bentuk hukum untuk memperoleh pengakuan masyarakat hukum adat di Indonesia masih tersebar dalam beberapa peraturan perundang-undangan. UU Desa Tahun 2014 juga memerintahkan untuk melakukan penataan kesatuan masyarakat hukum adat dengan menetapkannya menjadi Desa Adat. Kampung Tarung terletak di Kabupaten Sumba Barat merupakan suatu wilayah yang masyarakatnya masih hidup dengan hukum adat dan memiliki kepercayaan tersendiri, namun hingga saat ini belum mendapat pengakuan sebagai kesatuan masyarakat hukum adat ataupun desa adat. Beberapa mekanisme untuk mendapatkan pengakuan formil bagi masyarakat adat menghendaki adanya proses identifikasi dan validasi. Penelitian ini merupakan upaya pendahuluan dari proses tersebut dengan mendokumentasikan sejumlah hukum dan kebiasaan Adat di Kampung Tarung melalui metode wawancara. Hasil penelitian menunjukan upaya yuridis pengakuan eksistensi yang telah dilakukan para pemimpin adat dan Pemerintah Daerah.
\end{abstract}

Kata kunci: kampung tarung; kesatuan masyarakat hukum adat; desa; perlindungan difensif

\section{A. Pendahuluan}

Undang-Undang Dasar Republik Indonesia tahun 1945 (UUD 1945) mengakui satuan pemerintahan yang bersifat khusus atau istimewa, serta eksistensi dan kesatuan mayarakat hukum adat dengan segala hak kebudayaannya melalui beberapa pasal, antara lain Pasal 18B, Pasal 28c Ayat (1), Pasal 28i Ayat (3), dan Pasal 32. Meskipun demikian, pengaturan lebih lanjut mengenai hal ini, khususnya mengenai kesatuan masyarakat hukum adat, masih banyak meninggalkan persoalan.

Dalam Penjelasan Pasal 18 UUD 1945

sebelum perubahan dituliskan bahwa: 
"Dalam territoir Negara Indonesia terdapat lebih kurang 250 zelfbestuurende landschappen dan volksgemeenschappen, seperti desa di Jawa dan Bali, negeri di Minangkabau, dusun dan marga di Palembang dan sebagainya. Daerah-daerah itu mempunyai susunan asli, dan oleh karenanya dapat dianggap sebagai daerah yang bersifat istimewa. Negara Republik Indonesia menghormati kedudukan daerah-daerah istimewa tersebut dan segala peraturan negara yang mengenai daerah-daerah itu akan mengingati hak-hak asal-usul daerah tersebut."

Banyak terminologi yang saling terkait mengenai objek dari pengakuan dan penghormatan terhadap keistimewaan, kekhususan daerah, serta masyarakat berikut adat dan hak-hak kebudayaannya. Pemerintahan asli Indonesia sesungguhnya memang banyak coraknya, misalnya: Desa, Huta, Nagari, Gampong, dll (Koesoemaatmadja, 1979).

Pengaturan mengenai masyarakat hukum adat masih tersebar dalam beberapa peraturan perundang-undangan (Warman, 2012). Mekanisme untuk mendapatkan penetapan juga masih layak diperdebatkan, demikian pula dengan bentuk hukum untuk penetapan tersebut. Belum selesai dengan persoalan penetapan sebagai kesatuan masyarakat hukum adat, Pasal 96 UU Desa juga memerintahkan untuk melakukan penataan kesatuan masyarakat hukum adat dan menetapkannya menjadi Desa Adat.

Kenyataannya, di Indonesia masih ada masyarakat adat yang belum ditetapkan ataupun membingungkan statusnya sebagai kesatuan masyarakat hukum adat. Hal ini terjadi pada Kampung Tarung. Kampung Tarung adalah suatu wilayah yang terletak di Kelurahan Sobawawi, Kecamatan Loli, Kabupaten Sumba Barat, Provinsi Nusa Tenggara Timur Indonesia. Masyarakat Kampung Tarung masih hidup dengan hukum dan tata-cara adat dan memiliki kepercayaan tersendiri, karenanya sering disebut juga sebagai Kampung Adat.

Wignjosoebroto membedakan istilah masyarakat adat dan masyarakat hukum adat, yang dijelaskan melalui tabel berikut : (Hantoro, 2016)

\section{Tabel 1. Perbandingan Masyarakat Adat} dan Masyarakat Hukum Adat Masyarakat Adat Masyarakat Hukum Adat

\begin{tabular}{cc}
\hline Satuan manusia se - & Satuan manusia se - \\
identitas & wilayah (terirori) \\
Hidup secara de & Hidup secara de jure \\
facto & \\
Berbasis budaya & Berbasis politik \\
Independen dari & Bagian dari fungsi \\
struktur negara & dalam struktur negara \\
\hline
\end{tabular}

Jika menggunakan ciri ini, ketika masyarakat Kampung Tarung tidak hidup secara de jure dan hanya berbasis budaya, maka mereka hanya dikatakan sebagai masyarakat adat dan belum dapat diakui sebagai kesatuan masyarakat hukum adat.

Rato-Rato (sebutan bagi kepala-kepala kabisu atau suku di Sumba) di Kampung Tarung, khususnya Rato Rumata Tarung sebagai Rato yang memiliki kedudukan tertinggi secara spiritual, memahami bahwa dasar pertimbangan dari norma adat Marapu Sumba yang telah berusia ratusan tahun harus berjalan harmonis dengan peraturan perundang-undangan nasional yang kini positif berlaku. Oleh sebab itu, penegakan norma-norma adat di wilayah Tarung ditujukan untuk menghormati, melindungi, menegakkan dan memenuhi Hak-Hak Asasi Masyarakat Hukum Adat Marapu di Sumba Barat, khususnya wilayah Loli, sesuai dengan peraturan perundang-undangan nasional yang berlaku.

Pengakuan formal melalui hukum nasional harus berdampak pada wibawa dan kewenangan kepemimpinan adat, baik menurut adat Marapu Sumba Barat maupun menurut hukum nasional, sehingga secara substansial maupun mandatoris keberadaan mereka dapat memiliki alas hak atau legal standing sesuai dengan peraturan 
perundang-undangan nasional yang positif berlaku.

Beberapa mekanisme untuk mendapatkan pengakuan formil bagi masyarakat adat menghendaki adanya proses identifikasi dan validasi untuk memenuhi persyaratan dalam Pasal 18B ayat (2) UUD 1945. Meskipun terdapat beberapa peraturan perundang-undangan yang mengatur tentang bentuk hukum dan mekanisme pengakuan tehadap kesatuan masyarakat hukum adat, namun peraturan terakhir dan terdetail terdapat dalam Permendagri Nomor 52 Tahun 2014 tentang Pedoman Pengakuan dan Perlindungan Masyarakat Hukum Adat dan Peraturan pelaksana dari UU Desa 2014, yaitu Peraturan Pemerintah Nomor 43 Tahun 2014 dan perubahannya yaitu Peraturan Pemertintah Nomor 47 Tahun 2015.

Pada setiap mekanisme dalam aturanaturan tersebut, baik untuk mendapat pengakuan sebagai kesatuan masyarakat hukum adat maupun untuk penetapan desa adat, harus ada proses identifikasi. Identifikasi memerlukan bukti-bukti tertulis, sehingga salah satu upaya krusial yang harus dilakukan adalah melakukan proses literasi hukum adat yang selama ini berkembang dan ditransmisikan berdasarkan tradisi lisan.

Di samping itu, dalam hukum kekayaan intelektual komunal dikenal juga istilah perlindungan defensif, yang semata-mata bertujuan untuk mempertahankan hak yang sudah ada. Berbeda dari perlindungan hak kekayaan intelektual individual yang menciptakan hak-hak baru melalui proses pendaftaran atau registrasi, perlindungan defensif hak-hak kekayaan intelektual komunal bermodal utama dokumentasi (Palar, 2016). Perlindungan defensif ini dilakukan dengan cara mendeklarasikan kembali obyek beserta hak-hak yang sudah melekat pada obyek tersebut melalui basis data virtual yang resmi, yang dapat digunakan untuk kepentingan pembuktian di pengadilan. Dokumentasi juga menegaskan kembali hubungan hukum antara obyek dengan komunitas pemegang hak atau kustodiannya. Pembukaan akses yang meluas terhadap isi dokumentasi ini akan mencegah penyalahgunaan yang potensial dilakukan oleh pihak ketiga.

Bahan identifikasi terhadap pengakuan eksistensi kesatuan masyarakat hukum adat menurut peraturan perundangundangan adalah pembuktian hak asal-usul dan syarat atau kriteria dari masyarakat hukum adat tersebut. Hak asal-usul itu sendiri jenisnya antara lain yang menyangkut struktur kelembagaan, pengangkatan pimpinan, dan penyelenggaraan urusan. (Sujatmo, 2005). Sedangkan syarat atau kriteria 'masyarakat hukum adat' menurut Pasal 97 ayat (2) UU Desa 2014 adalah paling kurang memenuhi salah satu atau gabungan unsur berikut: masyarakat yang warganya memiliki perasaan bersama dalam kelompok; pranata pemerintahan adat; harta kekayaan dan/atau benda adat; dan/atau perangkat norma hukum adat.

Hal-hal yang dikemukakan di atas akan menjadi panduan dalam penggalian data pada penelitian ini. Permasalahan utama dalam penelitian ini adalah:

1. Bagaimana norma-norma adat yang berlaku di Kampung Tarung, yang bersifat tidak tertulis, khususnya hal-hal yang diperlukan sebagai bahan-bahan identifikasi?

2. Bagaimana upaya yuridis para pemimpin adat Kampung Tarung dan Pemerintah Daerah terhadap pengakuan eksistensi kesatuan masyarakat hukum adat Kampung Tarung?

Dokumentasi dari norma-norma adat inilah yang dimaksud sebagai proses literasi dalam penelitian ini. Proses ini diharapkan dapat menjadi pelengkap data atau persyaratan atau bahan identifikasi dalam upaya menemukan landasan hukum yang tepat bagi Kampung Tarung.

\section{B. Metode Penelitian}

Penelitian ini merupakan penelitian empiris yang bersifat yuridis antropologis, dengan cara menggali norma-norma yang tidak tertulis tetapi hidup dan mengikat dalam masyarakat adat Kampung Tarung. 
Penggalian dilakukan melalui narasumber utama, yakni para pemimpin adat di Kampung Tarung yang disebut para Rato. Obyek penelitian ini dipahami dengan pendekatan kualitatif. Data-data yang digali, dikumpulkan dan dianalisis merupakan data yang bersifat non numerikal. Pengumpulan data menggunakan teknik wawancara mendalam (in-depth interviews). Hasil wawancara diformulasikan dalam bentuk pencatatan. Formula yang telah dicatat kemudian dianalisis keterkaitannya dengan peraturan perundang-undangan.

\section{Hasil dan Pembahasan}

\section{Profil Kampung Adat Tarung}

Kabupaten Sumba Barat memiliki luas wilaya daratan 2.183,18 Km2 dengan jumlah penduduk 99.882 Jiwa (Kemendagri, 2017). Dalam wilayahnya terdapat 6 Kecamatan, 11 Kelurahan dan 63 Desa, dengan sebaran sebagi berikut (BPS Kab. Sumba Barat, 2017) :

Tabel 2. Sebaran Jumlah Desa dan Kelurahan di Kecamatan di Wilayah Kabupaten Sumba Barat

\begin{tabular}{l|c|c}
\hline \multirow{2}{*}{\multicolumn{1}{c|}{ Kecamatan }} & \multicolumn{2}{c}{$\begin{array}{c}\text { Jumlah } \\
\text { Desa/Kelurahan }\end{array}$} \\
\cline { 2 - 3 } & Desa & Kelurahan \\
\cline { 2 - 3 } & $\mathbf{2 0 1 5}$ & $\mathbf{2 0 1 5}$ \\
\hline Lamboya & 11 & 0 \\
\hline Wanokaka & 14 & 0 \\
\hline Laboya Barat & 4 & 0 \\
\hline Loli & 9 & 5 \\
\hline Kota Waikabubak & 7 & 6 \\
\hline Tana Righu & 18 & 0 \\
\hline Total Sumba Barat & $\mathbf{6 3}$ & $\mathbf{1 1}$ \\
\hline
\end{tabular}

Di tengah banyaknya jumlah desa di Sumba Barat, bahkan di Kecamatan Loli pun terdapat 9 Desa, Kampung Adat Tarung justru terletak di Kelurahan Sobawawi, Kecamatan Loli. Hal ini menjadi daya tarik tersendiri sebab Kampung Tarung dapat dikatakan sebagai warisan jaman megalitikum dengan segala adat-istiadatnya yang masih dengan teguh dijalankan, meskipun terletak di tengah wilayah kota.
Di Kampung Tarung terdapat sekitar 102 rumah panggung yang dibangun melingkari bukit dan dihuni sekitar 400 keluarga. Dalam satu rumah panggung yang berukuran sekitar 15 meter x 15 meter dihuni 3-4 keluarga. Di tengah bangunan melingkar tersebut terdapat 17 kubur batu berbentuk seperti meja. Bangunan di sana dibangun tanpa alat dan metode pertukangan modern namun rumah adat Sumba atau uma (rumah) merupakan bentuk bangunan adat dengan arsitektur vernacular pencakar langit (Liputan 6, 2016).

Kepercayaan lokal mayarakat Kampung Tarung adalah Marapu. Kampung Tarung menjadi perwujudan wajah asli budaya Sumba dan menjadi salah satu destinasi yang selalu masuk dalam daftar penjelajahan wisatawan di Sumba Barat (Liputan 6, 2016). Jumlah warga Tarung sekitar 1.530 jiwa dengan mata pencarian sebagai petani, perajin tenun ikat, dan pegawai negeri sipil (Liputan 6, 2016).

Pelataran di tengah lingkaran bangunan rumah-rumah menjadi tempat untuk menggelar ritual adat tahunan Wulla Poddu atau bulan suci. Wulla Poddu digelar setiap Oktober sampai November, tergantung posisi bulan. Di pelataran itu, setiap malam selama Wulla Poddu, digelar musik, tarian adat, ritual berburu ke hutan secara tradisional.

\section{Perasaan Bersama Dalam Kelompok}

Bushar Muhammad, menyitir ajaran "beslissingenleer" Ter Haar, menyatakan bahwa Hukum Adat itu adalah "keseluruhan peraturan yang menjelma dalam keputusankeputusan para fungsionaris hukum (dalam arti luas), yang mempunyai wibawa (macht), serta pengaruh (invloed), dan yang pelaksanaannya berlaku dengan serta-merta (spontan) dan dipatuhi sepenuh hati (Muhammad, 1986). Uraian Ter Haar tersebut terwujud nyata pada keputusankeputusan pemimpin adat Tarung yang berpengaruh, disegani dan dijalankan dengan sepenuh hati baik pada masa-masa sejahtera hingga masa-masa sulit yang mereka hadapi. 
Ratusan tahun sebelum Indonesia berdiri, masyarakat Tarung merupakan masyarakat adat yang mandiri, namun berbagai pergantian kebijakan pemerintah menunjukkan pasang surut politik hukum pemerintahan daerah di Indonesia yang turut andil dalam mengganggu kesejahteraan dan kemandirian mereka. Beberapa aturan negara yang kaku justru seperti menjadi 'paksaan' bagi mereka, misalnya dalam pengisian kolom agama dalam dokumendokumen kependudukan. Hingga 2015, hal ini seolah menjadi masalah besar bagi Pemerintah untuk memberikan pelayanan, misalnya pelayanan pemerintah berupa beras untuk masyarakat miskin, kartu Badan Penyelenggara Jaminan Sosial (BPJS) Kesehatan, bantuan tunai langsung, dan lainnya (Kompas, 2016).

Masyarakat Tarung sejak awal bertahan dan sejahtera dengan pengelolaan tanah-tanah ulayat, aset-aset adat berupa ternak dan benda-benda pusaka dengan sistem barter, hingga mereka mengenal sistem uang. Sistem keuangan modern telah menjadikan masyarakat Tarung miskin hanya karena aset tanah, rumah dan kekayaan budaya mereka yang sangat besar tidak memiliki nilai tukar yang sepadan. Mereka kemudian harus berpuas diri dengan memiliki sedikit uang tunai atau bahkan tidak sama sekali. Dengan demikian, Tarung seolah bertarung dalam tradisi leluhur dan desakan kemajuan kota (Kompas, 2016).

Kepatuhan pada adat dan semangat untuk memperjuangkan kesejahteraan serta hak-hak konstitusional masyarakat adat membuat para pemimpin Tarung menyadari kebutuhan akan pengakuan resmi bagi masyarakat Tarung. Ini adalah kebutuhan preservasi ekspresi budaya tradisional yang bersifat spiritual dan sakral, yang langsung berhubungan dengan makna hidup dan keseimbangan mental masyarakat Tarung.

Dalam konteks tersebut di atas, ritualritual adat seharusnya memang dapat terus hidup berdasarkan hukum dan kebiasaan adat yang tidak tertulis, karena hal itu merupakan hak-hak tradisional yang telah diakui keberadaannya dalam UUD 1945.
Mereka berharap dapat lebih leluasa untuk merevitalisasi kembali kemandirian original mereka berdasarkan kedaulatan nilai mereka sendiri. Kedaulatan nilai ini bisa berwujud pemberdayaan kembali sistem barter adat di antara mereka, mengkomodifikasi beberapa kekayaan tradisional mereka dengan cara yang tidak melanggar ketentuan-ketentuan adat, atau menjalin kerja sama institusional dengan pihak luar.

Kesadaran untuk membentuk kesatuan hukum secara de jure ini menghasilkan sebuah kesepakatan bersama yang mereka jadikan aturan dasar tertulis. Kesepakatan ini selesai dibentuk pada November 2015 dengan nama Aturan Dasar Ikatan Masyarakat Adat Marapu Loli, Sumba Barat, Nusa Tenggara Timur, yang berisi sebagian hukum dan tata cara adat serta kelembagaan adat. Aturan dasar ini menjadi bukti bahwa masyarakat Tarung benar-benar memiliki 'perasaan bersama dalam kelompok' yang menjadi kriteria pertama untuk dapat dikatakan sebagai kesatuan masyarakat hukum adat.

Perasaan bersama dalam kelompok yang telah teruji selama ratusan tahun bahkah harus diuji kembali oleh musibah teraktual yang terjadi pada 7 Oktober 2017. Kampung Tarung terbakar. Namun demikian, masyarakat segera menanggulangi musibah ini dan pada minggu akhir bulan Oktober 2017, keadaan telah pulih kembali dan mereka pun siap memasuki Wulla Poddu di tahun 2017 meskipun masih dalam keadaan berduka. Hal ini bisa dijadikan bukti adanya 'perasaan bersama dalam suatu kelompok' tersebut.

\section{Literasi Pranata Pemerintahan, Harta Kekayaan dan Perangkat Norma Hukum Adat}

Setelah penyelenggaran Wulla Poddu pada bulan Oktober sampai November 2015 di Kampung Tarung, Rato Rumata Lado Regi Tera telah berhasil menyelesaikan proses literasi sebagian hukum dan tata cara adat di sana. Proses ini berkaitan dengan kelembagaan adat. Proses literasi ini selesai pada tanggal 20 November 2015 dengan judul Aturan Dasar Ikatan Masyarakat Adat 
Marapu Loli, Sumba Barat, Nusa Tenggara Timur.

Rato Rumata dan para Rato di bawahnya sepakat bahwa penguatan lembaga adat harus berasaskan Pancasila, keadilan, kesetaraan antara umat beragama dan kepercayaan, kejujuran dan keterbukaan, toleransi, kepastian hukum, penjagaan wibawa dan martabat Masyarakat Adat Marapu, asas-asas dalam Hukum Adat Marapu, kebiasaan Adat Marapu yang tercermin dalam penyelenggaraan kehidupan sehari-hari meskipun tidak tertulis, serta tanggung jawab Negara yang diselenggarakan oleh Pemerintah, khususnya Pemerintah Daerah.

Detail dari Aturan Dasar ini mengatur tentang hak-hak dan kewajiban Masyarakat Adat Marapu di Loli, serta pengelolaan dan pelaksanaan hak-hak Masyarakat tersebut terhadap potensi-potensi dan kekayaan alam dan kekayaan budaya, termasuk ritual-ritual adat, yang berasal, hidup atau memiliki kaitan erat dengan warisan leluhur yang terapat di Kampung Tarung. Berikut adalah beberapa hal yang menjadi isi dari Aturan Dasar tersebut:

\section{a. Keanggotaan}

Keanggotaan Masyarakat Kampung Tarung bersifat sukarela, sehingga anggotanya terikat jika secara sadar memilih untuk berpartisipasi dalam sistem kemasyarakatan atau ritual-ritual yang diselenggarakan berdasarkan tatanan hukum dan tata-cara Marapu. Seorang Rato yang menjadi anggota sekaligus Pengurus Ikatan Masyarakat Adat Marapu Sumba harus selalu bertindak sebagai wakil dari suku atau kabisunya. Pendapat yang diberikannya tidak boleh bertentangan dengan aspirasi anggota-anggota suku atau kabisu yang diwakilinya.

\section{b. Sistem Kelembagaan}

Sistem kelembagaan dideklarasikan kembali dengan alasan-alasan sebagai berikut:
1) Penghormatan,
perlindungan,
penegakan dan pemajuan hak-hak dan
kewajiban adat sesuai dengan hukum nasional Indonesia

2) Membantu Pemerintah Daerah dalam merumuskan, melaksanakan, dan menegakkan hak-hak tradisional Masyakat Hukum Adat yang dijamin Konstitusi;

3) Menjalankan sistem susunan asli Masyarakat Hukum Adat;

4) Dikelola atas dasar komitmen moral dan spiritual para Rato untuk mempertahankan dan melestarikan warisan budaya Sumba, dengan sistem manajemen tradisional yang bersifat nirlaba;

5) Dapat membentuk lembaga lain berdasarkan struktur organisasi modern untuk mengelola kekayaan Adat yang diembannya untuk kesejahteraan masyarakat.

\section{c. Struktur Kepengurusan}

Struktur Kepengurusan Masyarakat Adat Kampung Tarung, terdiri dari:

1) Musyawarah Tertinggi, yakni forum yang terdiri dari Dewan Penasehat/Pembina dan Dewan Pelaksana, yang diketuai bersama-sama oleh Ketua Dewan Penasehat/Dewan Pembina dan Ketua Dewan Pelaksana;

2) Dewan Pelaksana, yang terdiri dari Ketua Dewan Pelaksana, Wakil KetuaI Dewan Pelaksana yang membidangi masalah-masalah Adat, Wakil Ketua II membidangi hubungan eksternal dengan Pemerintah Daerah, Sekretaris, Bendahara dan Kepala-Kepala Suku serta Kabisu.

Pengurus Masyarakat Adat Marapu dapat diajukan oleh masing-masing suku atau kabisu. Kepengurusan ini disesuaikan dengan tradisi pengembanan jabatan Rato dalam suatu suku dan kabisu, yang pada dasarnya berlangsung seumur hidup, kecuali jika Pengurus tersebut mengalami kondisi tidak terduga yang menyebabkannya tidak dapat lagi duduk sebagai Pengurus. Meskipun kedudukan seorang Pengurus Ikatan Masyarakat Adat Marapu Loli di dalam tuba-nya mengharuskan ia memegang kedudukan sebagai kepala tuba seumur hidup, ia dapat mengundurkan diri dari 
posisinya sebagai pengurus atas kemauannya sendiri.

\section{d. Tugas dan Kewenangan}

Dalam menjalankan hak dan kewajibannya, Pengurus harus menjaga integritas, obyektivitas, serta kemandiriannya agar tidak menimbulkan konflik kepentingan. Tugas dan kewenangan Pengurus Masyarakat Adat Marapu Loli adalah:

1) Menyusun kembali kegiatan-kegiatan adat yang telah hidup dalam Masyarakat Adat terkait secara reguler dan/atau berdasarkan kebutuhan;

2) Menetapkan rangkaian kegiatan adat sesuai dengan upaya pelestarian lingkungan atas tanah dan hutan Adat, misalnya: kewajiban menyebarkan bibit pada masa perburuan di hutan adat, dll.;

3) Melakukan pengawasan terhadap pelaksanaan hukum dan kebiasaan adat dalam kehidupan sehari-sehari;

4) Memberikan rekomendasi kepada Pemerintah Daerah menyangkut pelaksanaan kegiatan-kegiatan ritual adat dan kegiatan-kegiatan khusus lain;

5) Menetapkan tata-cara melaksanakan ritual adat ;

6) Melakukan hal-hal yang terkait dengan prosedur administratif untuk mengurus akta kelahiran, pernikahan, kematian, dan akta-akta kependudukan penting lain yang dibutuhkan untuk pembuktian atas peristiwa-peristiwa kependudukan yang telah dianggap sah secara Hukum Adat Marapu Sumba;

7) Mengelola hak-hak atas tanah dan hutan Ulayat Masyarakat Adat, termasuk: penetapan tapal batas, penetapan status tanah, penetapan dan pengaturan wilayah perburuan, termasuk perburuan yang termasuk dalam ritual adat;

8) Melakukan mediasi atau penyelesaian sengketa adat di luar pengadilan (non litigasi);

9) Memberikan pertanggungjawaban kepada seluruh anggota Masyarakat Ada tsecara reguler sepengetahuan Pemerintah Daerah setempat;

10) Melakukan evaluasi kegiatan.

\section{e. Mekanisme Pengambilan Keputusan dalam Tata-Cara Adat}

Mekanisme pengambilan keputusan dalam tata-cara Adat di Kampung Tarung berakar dari gotong-royong organis tradisional. Berikut adalah beberapa istilah mekanisme pengambilan keputusan antara lain ;

\section{1) Kabuburawa Kamalimaso}

(Musyawarah Mufakat) adalah rapat tertinggi yang dihadiri oleh seluruh Rato, untuk memutuskan masalah yang tidak dapat diselesaikan sendiri, merugikan suku atau kabisu atau yang memerlukan kesepakatan dari seluruh pimpinan.

2) Pakasana merupakan pertemuan terbatas di dalam Ikatan Masyarakat Adat Marapu di Loli atau di dalam suatu suku atau kabisu untuk membahas teknis pelaksanaan ritual adat maupun kegiatan Adat lainnya, misalnya: perencanaan membangun rumah adat, pesta adat, perkawinan adat, dll,

\section{f. Harta, Pendapatan, Pembiayaan dan Akuntabilitas}

Masyarakat Tarung memilik hak ulayat yang meliputi hak atas tanah adat di wilayah Kampung Tarung sendiri, hak atas tanah adat di bawah kaki bukit Kampung Tarung (Kebun Pamali), hak atas hamparan tanah adat di kawasan Loli, Waikabubak (Kebun), termasuk juga sawah Pamali, sawah komunitas, serta hutan adat. Selain itu masyaraat Tarung juga memiliki dan mengelola benda-benda pusaka yang menjadi kekayaannya.

Kebijakan mengenai jenis-jenis pendapatan, pembiayaan dan pertanggungjawaban keuangan dilaksanakan berdasarkan musyawarah. Dalam konteks ini, para Rato sadar bahwa masuknya sistem perekonomian modern dengan uang sebagai sarana pertukaran dan penilaian barang serta bank sebagai lembaga pengelola uang, mengharuskan kebijakan pengelolaan kekayaan adat dimodifikasi. Pengelolaan ini harus memenuhi persyaratan mendasar untuk menjadikan segala bentuk transaksi dilakukan secara tertulis, dengan mekanisme 
pertanggungjawaban yang terbuka dan transparan.

Menurut Aturan Dasar Lembaga Adat Marapu Loli, jenis-jenis pendapatan yang akan dikelola adalah:

1. Bantuan Pemerintah Daerah dan/atau Pemerintah Pusat maupun lembaga non Pemerintah;

2. Hibah dari institusi dan/atau perorangan;

3. Pembagian hasil pendapatan (benefit sharing) dari hasil penggunaan yang bersifat komersial dari Pengetahuan Tradisional dan/atau Ekspresi Budaya Tradisional Marapu oleh pihak ketiga, baik dari dalam maupun luar negeri, dalam bentuk moneter maupun non moneter;

4. Ganti rugi atau kompensasi atas eksploitasi tidak sah dari tanah Adat, hutan Adat, maupun kekayaan Adat lainnya yang telah diputus oleh Pengadilan atau lembaga non litigasi lainnya;

5. Pendapatan lain-lain yang sah dan tidak mengikat.

\section{g. Program Pemberdayaan dan Pelatihan}

Masyarakat Kampung Tarung juga berusaha untuk mengambil langkah-langkah yang efisien dan efektif agar masyarakat memiliki pemahaman komprehensif tentang hak-hak Masyarakat Adat Marapu dan Hukum serta Kebiasaan Adatnya.

\section{h. Pelanggaran Adat}

Pelanggaran Adat merupakan klasifikasi tindakan yang masih hidup di Kampung Tarung. Akibat hukum dari pelanggaran adat ini masih disegani dan bahkan ditakuti. Denda dan sanksi adat menjadi faktor pemberi efek jera yang seringkali lebih diutamakan dari pada sanksi dalam hukum positif nasional. Sanksi Adat sendiri berlaku terhadap pelanggaran Hukum atau Kebiasaan Adat Marapu, yang umumnya tidak tertulis, namun dibuktikan dengan persaksian warga Kampung. Sebagian sanksi bersifat pidana.

Dalam khazanah hukum adat tidak tertulis di Kampung Tarung, tindakan- tindakan yang merupakan Pelanggaran Adat adalah pembunuhan, perampokan dan pencurian, penipuan, pencemaran nama baik, pemerkosaan; dan perusakan benda bergerak, tidak bergerak, dan/atau lingkungan di wilayah ulayat.

\section{i. Penjatuhan Sanksi Adat}

Pemerintah seyogyanya mengakui dan menjamin keberlangsungan penyelesaian sengketa menurut Hukum dan Kebiasaan Adat Marapu di luar Pengadilan sebagai upaya non litigasi untuk meringankan beban Pengadilan secara lebih aspiratif, efektif dan efisien. Hal ini disebabkan kenyataan bahwa sejumlah penyelesaian sengketa adat lebih efisien dan efektif jika dilakukan menurut Hukum dan Kebiasaan Adat Marapu. Penyelesaian ini sering merupakan pilihan pertama dalam suatu Suku atau Kabisu.

Penjatuhan sanksi adat dilakukan berdasarkan keputusan dalam Musyawarah Tertinggi Ikatan Masyarakat Adat Marapu Sumba Barat (Lolina) Sanksi Adat dapat berbentuk sanksi material berupa uang, barang, hewan, dan/atau kutukan adat. Penjatuhan Sanksi Adat berupa kutukan adat merupakan upaya terakhir (ultimum remedium) setelah semua upaya, baik secara sosial maupun hukum, yang dilaksanakan di dalam maupun di luar Pengadilan menurut Hukum Nasional tuntas diupayakan. Penjatuhan kutukan adat ini hanya dapat dilakukan berdasarkan kewenangan dan tatacara Hukum dan Kebiasaan Adat Marapu yang berlaku dalam Suku atau Kabisu terkait. Jika dianggap perlu, upaya penyelesaian Sengketa Adat dapat diselesaikan secara adat bersama-sama dengan penyelesaian menurut hukum nasional.

\section{Upaya Menemukan Bentuk Hukum bagi Eksistensi Kampung Adat Tarung}

Bushar Muhammad mengutip pendapat Ter Haar yang bersaksi tentang persekutuan hukum adat yang telah ada dan berciri memiliki tatasusunan yang tetap dan kekal; tidak ada mempunyai pikiran akan membubarkan diri dan mempunyai 
pengurus dan harta benda, milik keduniaan dan milik gaib (Muhammad, 1986). Bahkan ketika Van Vollenhoven dalam bukunya yang diterjemahkan oleh Ateng Syafrudin, mempersaksikan bahwa: (Syafrudin, 1985)

"Ketika sebuah kapal berbendera tiga warna memasuki daerah Indonesia tahun 1596 daerah itu dalam arti hukum tata negara tidak merupakan tanah kosong dan tandus, melainkan penuh dengan lembaga-lembaga pengaturan masyarakat dan pemerintahan yang dikuasai atau berkekuasaan atas suku-suku bangsa, kesatuan perkampungan, republik-republik, dan kerajaankerajaan."

Masyarakat Tarung merupakan salah satu dari lembaga-lembaga pengaturan masyarakat yang dimaksud.

Ketika membahas mengenai sistem rumah tangga daerah, Bagir Manan mengatakan bahwa isi rumah tangga daerah dalam sistem rumah tangga formal tidak merupakan sesuatu yang diberikan (toekennen), tetapi sesuatu yang dibiarkan tumbuh (toelaten) dan kemudian diberi pengakuan (erkennen) (Manan, 1991). Selain itu, Bagir Manan juga mengatakan bahwa Indonesia, yang secara struktural, usianya lebih muda dari berbagai struktur pemerintahan asli ini, maka negara bukan membentuk, melainkan mengakui dan memberi ruang. Hal ini dapat pula dikontekskan pada eksistensi masyarakat hukum adat yang tidak bisa dikonstruksikan seolah pemerintah membentuk atau mereka dibebani dengan mekanisme idntifikasi atau pembuktian. Mereka hanya memerlukan pengakuan, perlindungan hak dan ruang untuk menjalankan adat kepercayaannya.

Seperti telah disinggung dalam pendahuluan, pengakuan kesatuan masyarakat hukum adat dan mekanismenya hingga saat ini masih tersebar di beberapa peraturan perundang-undangan. Namun demikian hadirnya UU Desa 2014 menjadi landasan hukum terbaru di level undangundang yang mengatur mengenai penataan kesatuan masyarakat hukum adat untuk ditetapkan menjadi desa adat.

Berdasarkan praktik yang berkembang saat ini, terdapat beberapa bentuk regulasi yang digunakan sebagai pengakuan terharap eksistensi kesatuan masyarakat hukum adat, antara lain Perda Pengaturan tentang Keberadaan dan Hak-Hak Masyarakat Hukum Adat, Perda Penetapan dan Perda Pembentukan Desa Adat. Beberapa bentuk regulasi tersebut merupakan alternatif bentuk hukum untuk pengakuan eksistensi masyarakat hukum adat. Namun demikian, Pemerintah Daerah Kabupaten Sumba Barat menempuh upaya yuridis tersendiri dengan mengeluarkan Keputusan Bupati tentang Pembentukan Lembaga Adat Kampung Situs Tarung. Bentuk hukum yang dipilih adalah keputusan bupati, bukan peraturan daerah.

Pada tanggal 20 Oktober 2017, Bupati Kabupaten Sumba Barat yang baru terpilih setelah Pemilihan Umum 2015, Drs. Agustinus Niga Dapawole mengeluarkan Keputusan Bupati Sumba Barat Nomor KEP/HK/588/2017 tentang Pembentukan Lembaga Adat Kampung Situs Tarung, Kelurahan Sobawawi, Kecamatan Loli, Kabupaten Sumba Barat, Tahun Anggaran 2017. Meskipun tindakan ini lebih dipicu oleh terjadinya kebakaran besar di Kampung Tarung ada tanggal 7 Oktober 2017, namun secara yuridis, hal ini dapat dilihat sebagai tanggapan atas hasil upaya literasi Aturan Dasar Ikatan Masyarakat Adat Marapu Loli, Sumba Barat, Nusa Tenggara Timur pada tanggal 20 November 2015.

Diktum dari Keputusan tersebut mendeklarasikan pembentukan Lembaga Adat di Tarung dengan nama Lembaga Adat Kampung Situs Tarung, Kelurahan Sobawawi, Kecamatan Loli, Kabupaten Sumba Barat Tahun Anggaran2017. Dalam keputusan tersebut, Lembaga Adat Kampung Situs Tarung ini mempunyai tugas dan kewenangan sebagai berikut: 
a. Melaksanakan ritual adat atau budaya secara rutin di dalam kawasan Kampung Situs Tarung;

b. Mempertahankan kekhasan atau keunikan dan keaslian adat atau budaya sebagaimana yang harus dimiliki oleh sebuah Kampung Situs Peninggalan Sejarah dan Purbakala;

c. Menginventarisir, memelihara dan mengawasi Cagar Budaya dan bertanggung jawab atas keberadaan benda-benda Cagar Budaya yang berada di dalam maupun di luar Kampung Situs.

Segala biaya yang timbul sebagai akibat ditetapkannya Keputusan ini dibebankan pada Anggaran Pendapatan dan Belanja Daerah Kabupaten Sumba Barat Tahun Anggaran 2017.

Banyak hal menarik yang dapat dicermati dari Keputusan Bupati ini, antara lain :

Pertama, nama Keputusan Bupati ini menggunakan terminologi 'pembentukan'. Kesatuan masyarakat hukum adat atau lembaga adat di Tarung bukan baru dibentuk pada tahun 2017, namun sudah ratusan tahun yang lalu, sehingga yang diperlukan adalah 'pengakuan' melalui 'penetapan'

Kedua, pada konsiderans mengingat yang memuat dasar hukum, Keputusan Bupati ini tidak merujuk pada UU Desa, Peraturan Pemerintah pelakasana UU Desa atau bahkan Permendagri Nomor 52 Tahun 2014 tentang Pedoman Pengakuan dan Perlindungan Masyarakat Hukum Adat.

Ketiga, apa yang dikemukakan pada bagian tugas dan kewenangan hanya berisi kewajiban bagi masyarakat kampung Tarung dan masih seputar pemeliharaan kawasan, benda-benda dan kewajiban untuk menjalankan ritual-ritual adat. Keputusan bupati tersebut belum menyentuh hal-hal yang sifatnya pemenuhan hak dasar, pemberdayaan ekonomi, dll.

Keempat, pernyataan pada diktum ketiga adalah mengenai segala biaya yang muncul dibebankan pada anggaran daerah 2017. Apakah hal ini berarti keputusan Bupati hanya berlaku untuk tahun anggaran 2017 dan tidak dianggap sebagai dasar hukum bagi eksistensi Kampung Tarung?

Kekhawatiran tentang hal keempat di atas ternyata terjadi. Dalam sebuah program bantuan dari Kementerian Pendidikan dan Kebudayaan (Kemendikbud) yang bertajuk "Fasilitasi Komunitas Budaya di Masyarakat dan Revitalisasi Desa Adat tahun 2017", Kampung Tarung turut mengirim proposal untuk mendapatkan bantuan tersebut. Ketiadaan status hukum sebagai 'desa adat' atau kesatuan masyarakat hukum adat membuat posisi lembaga adat Tarung dipersamakan dengan komunitas budaya, dan pihak Kemendikbud menyarankan untuk membuat akta notaris tentang 'Pendirian Lembaga Adat Kampung Situs Tarung'. Akta notaris dibuat pada 13 Desember 2017, berisi klausul-klausul selayaknya lembaga hukum privat seperti harta yang dipisahkan, ketentuan tentang struktur organisasi hingga kepailitan. Pertanyaannya, bagaimana mungkin sebuah entitas publik yang sejatinya hanya memerlukan 'pengakuan', dipersamakan dengan entitas privat yang baru dibentuk melalui akta notaris.

Pemerintah dan Masyarakat Kampung Tarung perlu menyadari dan memahami bahwa eksistensi entitas adat di Kampung Tarung merupakan warisan budaya yang telah ada sejak lama, bukan bentukan baru apalagi jika dikatakan baru terbentuk di tahun 2017. Hal yang perlu diperjuangkan adalah bentuk hukum sebagai pengakuan eksistensi tersebut, yang jika dikaitkan dengan persoalan nomenklatur saat ini adalah apakah sebagai masyarakat hukum adat atau sebagai desa adat dan keduanya dikukuhkan melalui peraturan Daerah. Upaya pengakuan eksitensi ini menjadi pangkal dari usaha-usaha pelestarian lainnya baik cagar budaya maupun warisan adat tak benda yang akan berujung pada kekayaan intelektual komunal.

\section{Simpulan}

Mekanisme untuk memperoleh pengakuan sebagai kesatuan masyarakat hukum adat atau desa adat, menghendaki adanya proses identifikasi dan validasi. 
Proses ini dimulai dengan meliterasi atau mendokumentasikan hal-hal yang menjadi identitas utama atau kriteria masyarakat hukum adat. Idealnya, proses ini dilanjutkan dengan pengakuan tertulis dari Pemerintah Daerah sebagai bukti keberadaan lembaga Adat Marapu sebagai kustodian utama. Pengakuan tertulis Pemerintah Daerah dapat dipandang sebagai dasar bagi upaya inklusi sosial yang berkelanjutan, sehingga normanorma, kearifan dan ekspresi-ekspresi tersebut dapat menjadi sumber daya budaya andalan yang tumbuh dari dalam masyarakat hukum adat di Kampung Tarung sendiri.

Para pemimpin adat Kampung Tarung telah memulai proses literasi ini dengan mengeluarkan Aturan Dasar Ikatan Masyarakat Adat Marapu di tahun 2015. Kemudian di tahun 2017 Pemerintah Daerah Kabupaten Sumba Barat mengeluarkan Keputusan Bupati Nomor KEP/HK/588/2017 tentang Pembentukan Lembaga Adat Kampung Situs Tarung. Pada Desember 2017 para Rato di Kampung Tarung juga telah membuat Akta Notaris tentang Pendirian Lembaga Adat Situs Tarung sebagai syarat untuk mengikuti program bantuan revitalisasi rumah adat dari Kemendikbud.

Keputusan Bupati Sumba Barat dapat dilihat sebagai upaya positif Pemerintah Daerah untuk mengakui secara formal eksistensi Lembaga Adat, meskipun masih banyak yang dapat dipertanyakan dan belum menyinggung detail mengenai hukum adat dan tata-cara adat dalam Aturan Dasar versi komunitas 2015. Demikian pula dengan legalisasi lembaga adat melalui akta notaris, tetap merupakan usaha dari para peminpin Adat Tarung untuk terus mengupayakan yang terbaik bagi masyarakatnya. Hal ini menjadikan Kabupaten Sumba Barat sebagai salah satu daerah yang telah berani mengambil langkah yuridis untuk menjaga aset budaya, yakni dengan mengakui eksistensi masyarakat hukum adat selaku kustodian warisan budaya sesuai dengan hak asasi dan hak konstitusionalnya.

$\mathrm{Ke}$ depan, diperlukan penelitian lanjutan untuk menentukan langkah lebih lanjut dari Keputusan Bupati dan akta notaris tentang Pembentukan/Pendirian Lembaga Adat Kampung Situs Tarung, serta merumuskan bentuk hukum yang tepat dan memberi manfaat optimal bagi masyarakat Kampung Adat Tarung. Jika pemerintah jeli serta mampu mengembangkan potensi yang ada, eksistensi masyarakat adat Tarung merupakan aset yang sangat membanggakan. Peran pemerintah dapat menjadi solusi, bukan hanya untuk kesejahteraan masyarakat Tarung, namun juga untuk menjadi bagian dari kebanggaan Indonesia

\section{DAFTAR PUSTAKA}

Hantoro, N.M. (2016) Penetapan Kesatuan Masyarakat Hukum Adat Sebagai Bentuk Pengakuan Negara dan Implikasinya. In Fuad, F (Eds). Negara dan Masyarakat Hukum Adat. Jakarta: Pusat Penelitian Badan Keahlian DPR RI dan Dian Rakyat.

Koesoemahatmadja,R.D.H. (1979). Pengantar Ke Arah Sistem Pemerintahan Daerah Di Indonesia, Bandung : Bina Cipta.

Manan, B. (1991), Suatu Kajian Ulang Atas UU No. 5 Tahun 1974, Majalah Projustitia No. 2 Tahun IX, April.

Muhammad,B. (1986) Asas-Asas Hukum Adat, Suatu Pengantar, Jakarta:Pradnya Paramita.

Palar, M.R.A. Ciarolla, C. Wendland, W. (2016). In Documentation of $T K$ and TCEs : the IP Dimension, WIPO-Group of 15 Workshop on Genetic Resources, Traditional Knowledge, Traditional Cultural Expressions', Power Points Presentation, Workshop on Intellectual Property and Genetic Resources, Traditional Knowledge and Traditional Cutlural Expresions for the Group of 15. Algeria : WIPO.

Syafrudin, A. (1985) Bahan Bacaan Ringkas Hukum Pemerintahan di Daerah, Bandung:Unpad. 
Sujamto. (2005). Daerah Istimewa Dalam Negara Kesatuan Republik Indonesia. In Huda, Hukum Tata Negara Indonesia (p 288). Jakarta: PT. Raja Grafindo Persada.

Warman K. Peta Perundang-undangan tentang Pengakuan Hak Masyarakat Hukum Adat. Retrieved from http://procurementnotices.undp.org/view_file.cfm?doc_id $=39284$

http://www.kemendagri.go.id/pages/profildaerah/kabupaten/id/53/name/nusa tenggaratimur/detail/5312/sumba-barat https://sumbabaratkab.bps.go.id/dynamictabl e/2016/08/05/9/banyaknya-desakelurahan-menurut-kecamatan-dikabupaten-sumba-barat-2015.html https://travel.kompas.com/read/2016/05/25/1 54500727/Kampung.Adat.Tarung.Berta han.di.Era.Modern.

https://www.liputan6.com/regional/read/312 2218/keindahan-kampung-adat-tarungdi-sumba-barat-tinggal-kenangan https://www.liputan6.com/regional/read/312 2218/keindahan-kampung-adat-tarungdi-sumba-barat-tinggal-kenangan 